\title{
Dinamika Maskulinitas dan Nasionalisme Masyarakat Jawa di Era Majapahit
}

\author{
Mega Widyawati a,1*, Eggy Fajar Andalas b,2 \\ a Universitas Muhammadiyah Malang, Jalan Tlogomas 246 Malang, Indonesia, 65144 \\ ${ }^{1}$ megawdwt98@gmail.com; ${ }^{2}$ eggy@umm.ac.id \\ * Corresponding Author
}

\begin{tabular}{l}
\hline INFO ARTIKEL \\
Sejarah Artikel: \\
Diterima: 12 November \\
2020 \\
Direvisi: 12 November \\
2020 \\
Disetujui: 15 November \\
2020 \\
Tersedia Daring: 16 \\
November 2020
\end{tabular}

Kata Kunci:

Jawa

Kerajaan Majapahit

Maskulinitas

Nasionalisme

\begin{abstract}
ABSTRAK
Maskulinitas dan nasionalisme selama ini menggambarkan fenomena di mana konsepsi negara atau bangsa, termasuk bagian dari kedaulatan dan identitas yang berkontribusi dalam kaitannya dengan peran gender. Artinya, mikrokultur maskulinitas dalam kehidupan sehari-hari mengartikulasikan dengan sangat baik dengan tuntutan nasionalisme. Penelitian ini bertujuan untuk mendeskripsikan bentuk-bentuk maskulinitas dan nasionalisme yang beroperasi pada kultur masyarakat Jawa dahulu, tepatnya pada era Kerajaan Majapahit. Penelitian ini menggunakan metode kualitatif deskriptif. Sumber data penelitian berupa novel Jayaning Majapahit (2014) karya Agus S. Soerono. Teknik pengumpulan data memakai teknik baca-catat. Analisis data dilakukan dengan menyajikan data, menginterpretasi data, dan menarik kesimpulan berdasarkan tujuan yang dinyatakan. Hasil analisis menunjukkan bahwa novel Jayaning Majapahit mewacanakan kedudukan tokoh laki-laki lebih mendominasi dalam urusan kedaulatan kerajaan Majapahit, baik dalam urusan mengatur strategi politik dalam pemerintahan maupun mengatur strategi perang. Melalui dua bentuk dominasi maskulinitas, masyarakat majapahit lebih spesifiknya pada laki-laki berada di level tertinggi dalam situasi posisi terkait menjaga dan mempertahankan nasionalisme kerajaan.

\section{ABSTRACT}

Masculinity dan nationalism have been describing phenomena in which the conception of the state or nation, including parts of sovereignty dan identity that contribute in relation to gender roles. That is, the microculture of masculinity in everyday life articulates very well with the demdans of nationalism. This study aims to describe the forms of masculinity dan nationalism that operated in the culture of the Javanese community first, precisely in the era of the Majapahit Kingdom. This research uses descriptive qualitative method. The source of research data is Jayaning Majapahit (2014) written by Agus S. Soerono. The technique of data collection uses the notetaking technique. Data analysis is performed by presenting data, interpretation data, dan conclusions based on stated objectiv. The results of the analysis show that the novel Jayaning Majapahit discourse the position of male characters dominates in matters of the sovereignty of the Majapahit kingdom, both in matters of regulating political strategy in government dan regulating war strategy. Through two forms of dominance of masculinity, Majapahit society is more specifically in men who are at the highest level in a position related to guarding dan defending nationalism of the kingdom
\end{abstract}

Keywords:

Java

Majapahit Kingdom

Masculinity

Nasiionalism 
How to Cite: Widyawati, M., \& Andalas, E. F. (2020). Dinamika Maskulinitas dan Nasionalisme Masyarakat Jawa di Era Majapahit. JURNAL SATWIKA, 4 (2), 116-129. doi: https://doi.org/10.22219\%20/SATWIKA.Vol4.No2.116-129.

\section{Pendahuluan}

Maskulinitas merupakan kerangka pikiran dari masyarakat yang hampir sejajar dengan feminitas (Syaifullah, 2016:26). Kedua oposisi gender ini menjadi paradigma nyata bahwa tanpa adanya feminitas, posisi maskulinitas tidak akan tampak jelas. Dinamika maskulinitas mengartikulasikan sosok laki-laki secara idealitas dapat mencapai standar nilai tertentu, baik dalam bentuk fisik, kekuatan, daya nalar, kemampuan ekonomi, maupun obsesi (Huda, 2017:1080).

Dinamika maskulinitas memiliki kecenderungan bahwa gender berperan dalam membentuk pribadi seseorang melalui sikap dan perilaku dengan ditandai beberapa hal di antaranya; heteroseksual, indivisualis, agresif, kompetitif dan lain-lain. (Jatnika dan Hermawan, 2018:63). Kecenderungan ini hadir melalui bentuk konstruksi berupa tembok pembatas yang membentangkan jarak antara posisi laki-laki dan perempuan dalam tatanan masyarakat.

Konstruksi maskulinitas laki-laki adalah bentuk adaptasi dari lingkungan yang mengelilinginya, seperti halnya aturan dan atribut budaya. Penanaman konstruksi ini terjadi sejak mereka terlahir ke dunia sampai dewasa (Demartoto, 2010:1-2). Waktu yang demikian itu, lambat laun dapat menciptakan visualisasi diri dalam realitas kehidupan lakilaki.

Visualisasi diri terbentuk secara turuntemurun, dari generasi ke generasi, melalui mekanisme pewarisan budaya sehingga menjadi suatu kewajiban bagi seorang lakilaki yang harus dijalani jika ingin dianggap sebagai laki-laki sejati. Visualisasi diri pada laki-laki ini dapat ditunjukkan dengan karakteristik keberanian, pantang menyerah, tangguh, bertanggung jawab serta pemikiran yang rasional (Widiana, 2017:4). Apabila karakter ini dengan ataupun tidak sengaja mulai ditinggalkan dapat memberikan dampak yang esensial, seperti akan dianggap sebagai laki-laki yang memiliki sifat bertolak belakang dari yang diidealkan. Dari pengertian ini menunjukkan bahwa dalam penetapan peran laki-laki ialah hasil penerapan dan bentuk konstruksi sosial yang tertanam dalam masyarakat adalah suatu keharusan.

Dalam budaya Jawa, deskripsi maskulinitas dapat dilihat melalui tokoh pewayangan, di antaranya; Yudhistira, Bima, Arjuna, Bima, Nakula, dan Sadewa, Abimayu, Gathotkaca, dan yang lainnya (Budiman, Priyatna dan Mulyadi, 2019:135). Penggambaran ini tidak semata-mata tanpa adanya alasan, namun berdasarkan pada sebuah aturan tidak tertulis yang mendikte bahwa laki-laki sejati harus memiliki jiwa kesatria, pantang untuk menangis, harus tampak tegar, kuat, pemberani, garang serta berotot (Demartoto, 2010:2). Selain itu, beberapa kisah laki-laki yang dianggap maskulin dapat dijumpai melalui kisah peperangan pada saat Indonesia dalam periode kerajaan di Nusantara.

Novel Jayaning Majapahit menceritakan dua kisah. Pertama, menceritakan tentang pemerintahan Sri Ratu Tunggadewi, anak dari Raden Wijaya dengan Putri Gayatri Rajapatni, pada saat Kerajaan Majapahit memasuki kepemimpinan III. Pemerintahan Sri Ratu Tunggadewi dimulai dari terpilihnya Gajah Mada sebagai Mahapatih. Setelah mengucapkan Sumpah Amukti Palapa, Gajah Mada menunjuk seorang Laksmana bernama Rakryan Nala sekaligus memberikan tugas untuk membangun armada laut guna memperkuat pertahanan kerajaan dengan membangun saluran air di sekitar Pusat Kerajaan Majapahit. Kedua, objek penelitian berbicara mengenai runtuhnya Kerajaan Singasari di bawah pimpinan Kertanegara akibat ditakhlukkan oleh Jayakatwang dari Kerajaan Kadiri. Setelah runtuh, Raden Wijaya, sebagai menantu Kertanegara, ingin membalaskan dendam atas kematian 
mertuanya melalui bantuan pasukan dari Mongolia. Berlandaskan hal inilah, perang antara Raden Wijaya dan Jayakatwang tidak dapat dihind arkan.

Berdasarkan kedua kisah tersebut, kerangka gender yang dibangun dalam novel Jayaning Majapahit lebih condong pada sisi maskulinitas yakni memperlihatkan problematika pada laki-laki yang berasosiasi dengan ideologi kerajaan, strategi, kedaulatan, dan peperangan. Lazim ini diuraikan melalui peran dan daya upaya yang dilakukan beberapa tokoh laki-laki dalam novel seperti upaya menjaga kedaulatan kerajaan dari ancaman dari dalam dan luar kerajaan, sebagaimana yang direfleksikan pada sikap dan perilaku individu yang nasionalis.

Melalui tokoh Gajah Mada yang memiliki sifat rasional dan berpegang teguh dengan janjinya setelah mengucapkan sumpah Amukti palapa untuk selalu menjaga keutuhan dan kedaulatan kerajaan melalui perannya sebagai seorang Mahapatih, sekaligus untuk memenuhi cita-citanya memperluas wilayah kekuasaan Majapahit. Keseluruhan cerita tampak jelas menarasikan adanya dinamika maskulinitas yang dibangun Agus S. Soerono untuk memperjelas peran maskulinitas para tokoh diimbangi dengam peran nasionalisme untuk membangun kerajaan. Apabila dilihat secara kritis, tokoh laki-laki tersebut dalam praktik sehari-hari menggambarkan ukuran maskulin dalam urusan nasionalisme. Pendapat ini sebanding dengan gagasan Joane Nagel (1998) yang merumuskan teori maskulinitas dan nasionalisme.

Bersumber pada teori maskulinitas dan nasionalisme Nagel (1998), ditafsirkan bahwa nasionalisme memiliki relasi erat dengan politisi suatu bangsa. Selain itu, nasionalisme juga beroperasi dalam mengatur institusi dan militer. Dalam perjalanannya sejak dahulu, posisi laki-laki terus mengalami pergerakan. Berdasarkan hal itu, budaya mulai mengatur hegemoni maskulinitas seiring berjalannya waktu hingga menjadi sejalan dengan hegemoni nasionalisme. Dengan demikian, posisi maskulinitas dan nasionalisme saling berkaitan satu sama lain. (Budiman dan Sofianto, 2018:167).

Maskulinitas dan nasionalisme laki-laki dalam urusan institusi bangsa ditunjukkan melalui peran dan baktinya kepada negara sebagai rasa nasionalisme, maka tokoh-tokoh yang telah terikat dalam institusi negara tersebut harus mulai membiasakan diri untuk mengikuti praktik-praktik pendisiplinan diri yang sudah ditentukan. Implikasi sesungguhnya dari nasionalisme memiliki tujuan untuk mewujudkan pandangan, wawasan, dan perilaku suatu bangsa yang terjalin karena adanya kesamaan nasib, tanggung jawab serta hidup bersama-sama secara mandiri. Di samping itu, nasionalisme sebagai bentuk ideologis yang memiliki sifat dinamis sesuai dengan realitas sosial yang berjalan di kehidupan masyarakat.

Secara diakronus, kisah ini termasuk bagian dari nasionalisme gelombang satu, sejalan dengan pembagian dinamika nasionalisme yang dilakukan oleh Wiyatmi (2013:180), tahapan tersebut diantananya; nasionalisme gelombang pertama atau nasionalisme prakemerdekaan, nasionalisme gelombang kedua atau nasionalisme pascakemerdekaan, dan nasionalisme gelombang ketiga atau nasionalisme Indonesia baru.

Tulisan ini memiliki tendensi mendeskripsikan seperti apa dinamika maskulinitas dan nasionalisme yang beroperasi pada kultur masyarakat Jawa kuna. Kedua topik yang penulis angkat adalah dua konsep yang saling berkontribusi untuk menganalisis permasalah dalam novel Jayaning Majapahit. Nasionalisme yang akan dibahas pada penelitian ini adalah nasionalisme prakemerdekaan, di mana latar waktu sangat jauh dengan kemerdekaan (1945). Latar belakang penulis memilih topik ini karena ingin mengetahui peran tokoh lakilaki dalam menyikapi persoalan gender melalui peran dan tindakan yang berkaitan dengan dinamika maskulinitas dan nasionalisme, tepatnya yang terjadi pada abad ke 14, yakni sebelum kedatangan bangsa koloni yang memberikan studi 
nasionalisme. Peran laki-laki yang mendominasi dalam relasi politik memungkinkan bagi penulis untuk menemukan titik temu dari dinamika serta konstruksi dari maskulinitas itu sendiri. Sedangkan pada nasionalisme, akar-akar budaya nasionalisme akan dicoba untuk dipaparkan berdasarkan sifatnya yang nyata karena interpretasinya.

Kajian maskulinitas dan nasionalisme pernah dilakukan oleh Budiman dan Sofianto (2014) dengan sumber data berupa film Jenderal Soedirman (2015). Keduanya meneliti konstruksi maskulinitas dan nasionalisme melalui tokoh laki-laki berprofesi sebagai tentara yang bertugas pasca Orde baru. Hasil penelitian menunjukkan bahwa kerangka maskulinitas yang terbentuk antara relasi pihak sipil dan militer telah menempatkan pihak militer sebagai pihak yang lebih maskulin, sehingga adanya posisi ganda pada tokoh Soedirman memiliki dua peran sekaligus, peran "bapak" dalam keluarga dan peran "bapak" dalam dunia kemiliteran. Dengan demikian, posisi ideologis militer dari peran laki-laki lebih cenderung menempatkan peran yang loyalitas terhad ap negara dibandingkan peran dalam keluarga.

Penelitian ini penting untuk dilakukan karena beberapa alasan berikut. Pertama, sepengetahuan penulis objek material Novel Jayaning Majapahit belum pernah diteliti oleh peneliti sebelumnya, sehingga ini merupakan objek material baru yang coba dianalisi penulis untuk menjadi suatu pengetahuan baru mengenai maskulinitas dan nasionalisme. Kedua, novel ini berbicara mengenai dinamika maskulinitas dan nasionalisme tokoh laki-laki dalam hal politik kerajaan, strategi dan perang pada abad ke-14 untuk mempertahankan wilayah kekuasaan, sehingga pemahaman terhadap hal tersebut akan memberikan suatu pengetahuan baru dalam konteks maskulinitas dan nasionalisme laki-laki dalam urusan politik, strategi dan perang dalam masyarakat Tanah Jawa pada masa itu. Ketiga, penulisan Novel ini berlanadaskan dari kisah masa lalu ketika kerajaan
Majapahit masih berjaya sehingga penggambaran maskulinitas yang coba direfleksikan peneliti akan dideskripsikan berdasar pada bentuk konstruksi yang telah dibentuk oleh masyarakat Tanah Jawa.

\section{Metode}

Penelitian ini menggunakan metode kualitatif deskriptif dalam mendeskripsikan dinamika maskulinitas dan nasionalisme dari karya sastra, yakni Novel Jayaning Majapahit karya Agus S. Soerono. Penelitian menggunakan metode deskripsi kualitatif. Artinya, fitur-fitur analisis akan dilakukan sebagai berikut (Endraswara, 2011); (1) penulis memegang instrumen kunci yang akan membaca objek penelitian dengan teliti, (2) penelitian dilakukan secara deskriptif, artinya analisis penelitian akan dipecah dalam bentuk kata-kata. (3) proses penelitian lebih memprioritaskan hasil, karena objek berupa karya sastra adalah suatu fenomena yang mengundang banyak interpretasi, analisis induktif, dan fundamental.

Sumber data penelitian adalah novel Jayaning Majapahit karya Agus S. Soerono yang diterbitkan oleh Gramedia Pustaka Utama (GPU), cetakan pertama, Desember 2014, dengan ketebalan 147 halaman. Adapun data penelitian diambil dari hasil analisi dalam mendeskripsikan dinamika maskulinitas dan nasionalisme yang terkandung dalam novel Jayaning Majapahit, yakni berupa kutipan-kutipan, kata-kata, dan kalimat-kalimat yang menunjukan adanya maskulinitas dan nasionalisme. Sumber data pendukung penelitian bersumber dari buku-buku yang relevan dengan topik kajian seperti bukubuku teori penelitian dan jurnal-jurnal ilmu humaniora yang berkaitan dengan objek dan kajian.

Teknik pengumpulan data memakai teknik baca-catat. Teknik baca-catat dilakukan dengan membaca novel Jayaning Majapahit secara teliti, serta memahami secara mendalam sehingga akan diperoleh totalitas makna untuk menelusuri peristiwa yang terjadi sebagai data penelitian. Selama proses baca-catat, gagasan yang 
berhubungan dengan kriteria fokus penelitian akan ditandai, dicatat, kemudian diulas setelah proses baca-catat selesai. Dengan metode ini, data yang telah dikumpulkan akan diidentifikasi, dianalisis, dijelaskan, kemudian ditafsirkan sesuai dengan tujuan penelitian yang dinyatakan.

\section{Hasil dan Pembahasan}

\subsection{Bentuk-Bentuk Maskulinitas}

Bentuk-bentuk maskulinitas terbagi atas beberapa bentuk, di antaranya; aspek fisik, ekonomi, seksual, psikologi, sosiologi, dan personal. Bentuk-bentuk maskulinitas yang terdapat pada tokoh Gajah Mada dalam novel Jayaning Majapahit berdasarkan analisis data telah ditemukan 3 bentuk, di antaranya; aspek fisik, aspek ekonomi, dan aspek seksual.

\section{Aspek Fisik}

Bentuk maskulinitas yang ditemukan pada tokoh Gajah Mada dari aspek fisik hanya memenuhi satu indikator, yaitu kekuatan tubuh yang kuat. Hal ini tergambarkan dalam kutipan data berikut.

Lelaki tegap berbadan kokoh itu bertelanjang dada. Sebuah selempang yang melilit lehernya menjurai ke pinggangnya dan ujungnya diselipkan ke bawah ikat pinggang lebar yang mem belit pinggangnya (Soerono, 2014:9).

Indikator dari bentuk fisik tersebut tergambarkan melalui datayang menekankan pada tampilan fisik tokoh yakni tubuh yang kokoh dan kuat. Kategori laki-laki maskulin yang memperlihatkan tampilan fisik inilah yang menjadi dasar bahwa laki-laki dengan gambaran tersebut akan cenderung dikatanan ideal dan cocok untuk menjadi seorang pemimpin. Bahkan, dalam perbuatan yang bersifat buruk sekalipun, melalui sudut pandang peran gender maskulin tetap akan dianggap lebih dominan sehingga akan memiliki peranan besar dalam struktural masyarakat (Syaifullah, 2016:26).

Tindakan dan peranan Gajah Mada telah melewati proses konstruksi yang dibentuk, dikelola, dan diatur, melalui berbagai bentuk pendisiplinan tubuh serta mental melalui berperang. Pendisiplinan ini secara visual dikodekan berdasarkan mise en scene, yakni tubuh laki-laki dan beserta atribut yang melekat padanya divisualisasikan dalam komposisi sebagai pribadi yang teratur, rapi, memakai baju perang, cara berlatih mengangkat senjata, berbaris, menyimpan sepatu, hingga cara makan (Budiman, Priyatna dan Mulyadi, 2019:137). Hal ini menunjukkan bahwa dalam dinamika maskulinitas, segala aktivitas keseharian laki-laki, bahkan yang sangat personal pun, turut diatur dan dibentuk oleh aturan tidak tertulis sebagai bagian dari institusi negara.

\section{Aspek Ekonomi}

Bentuk maskulinitas yang ditemukan pada tokoh Gajah Mada dari aspek ekonomi hanya memenuhi satu indikator, yaitu jabatan. Hal ini tergambarkan dalam kutipan data berikut.

Selempang yang terbuat dari emas itu bertatahkan batu permata berwarna-warni dengan bentuk lingkaran yang makin ke bawah makin melebar. Pada bagian bawah selempang itu terdapat sebuah medali emas berbentuk bulat sebesar lingkaran yang terbentuk dari jempol dan telunjuknya. Medali itu adalah Surya Majapahit. Hanya sedikit sekali orang di Majapahit yang berhak menggunakan medali sejenis itu. Karena medali itu adalah medali jabatan bagi para petingg $i$ Kerajaan Majapahit. Rambutnya yang hitam lebat, sebagian digelung ke atas, dan sebagian lagi terurai ke belakang, hingga sedikit di bawah pundak. Di kedua telinganya kiri dan kanan terdapat masingmasing sebuah sumping yang indah. Pada lengan kiri-kanannya terdapat sebuah gelang yang cukup besar yang juga terbuat dari emas. (Soerono, 2014:9).

Kutipan data di atas menginterpretasikan bahwa bentuk maskulinitas dari aspek ekonomi dapat dilihat dari jabatan yang dimiliki tokoh Gajah 
Mada, yakni sebagai Mahapatih Kerajaan Majapahit. Kemudian, beban dan kewajiban dari jabatan tersebut diperjelas melalui atribut perlengkapan yang digunakan oleh tokoh Gajah Mada seperti "selempang yang terbuat dari emas," "medali emas," "sumping," dan "gelang emas." Semua atribut tersebut memberikan suatu simbol bentuk dari maskulinitas yang dipengaruhi oleh peran dan jabatan tokoh dalam suatu tatanan institusi kerajaan.

Jabatan yang dimiliki tokoh itu dinarasikan secara jelas, bahwa Gajah Mada menempati posisi sebagai Mahapatih. Kekuasaan yang dimiliki Gajah Mada ini menginterpretasikan eksistensinya dalam ranah politik kerajaan yang dapat mendominasi serta mengontrol. Hal ini merumuskan adanya kekuasaan yang menjadi salah satu relasi antara wacana kekuasaan dan masyarakat.

Kekuasaan memegang wacana penting dalam kaitannya dengan pengontrolan atau pengawasan terhadap suatu lembaga. Penggambarannya, apabila satu orang atau kelompok tertentu memegang kekuasaan, maka mereka dapat mengontrol tindak dan tutur secara keseluruhan. Pada dasarnya, kontrol tidak harus selalu dalam bentuk fisik, namun juga dalam bentuk kontrol secara mental atau psikis. Melalui konsep ini, maka kelompok yang dominan memungkinkan untuk membuat kelompok lain bertindak seperti yang diingingkannya (Syaifullah, 2016:26).

\section{Aspek Seksual}

Bentuk maskulinitas yang ditemukan pada tokoh Gajah Mada dari aspek seksual hanya memenuhi satu indikator, yaitu status lajang. Hal ini tergambarkan dalam kutipan data berikut.

\footnotetext{
"Aku tidak akan kawin, menikah atau menyentuh wanita, jika gegayuhanku untuk mempersatukan Nusantara di bawah panji-panji kebesaran Kerajaan Majapahit ini belum tercapai," kata Gajah Mada tegas.
}

"Sungguh berat gegayuhanmu itu,
Ngger," ujar gurunya. (Soerono,
2014:10)

Kutipan data di atas menginterpretasikan status lajang yang diteriman oleh Gajah Mada. Ia bersumpah untuk tidak akan menikah seumur hidup. Kebersediaan tokoh untuk tidak menikah merupakan simbol kebebasan dari agresifitas laki-laki. Hal ini dilakukan oleh tokoh Gajah Mada, karena ia menginginkan seluruh hidupnya dibaktikan untuk membentuk kejayaan Majapahit dibandingkan untuk urusan pribadi.

\subsection{Kedaulatan Laut; Simbol Kekuasaan Majapahit}

Ketika Majapahit menapaki kejayaan, kedaulatan laut menjadi suatu kebanggaan bahkan menjadi suatu identitas. Indonesia sejak dahulu telah dikenal sebagai negara maritim yang memiliki banyak kepulauan. Hal ini jelas sebagai suatu sumber kekuatan terbesar dan strategis untuk menjadikan laut sebagai suatu kedaulatan. Selain sebagai kedaulatan, wilayah laut juga menjadi bagian dari perputaran eksploitasi sumber daya alam sekaligus alat pertahanan. Inilah cara pandang yang kemudian dipakai oleh penguasa masyarakat Jawa pada zaman kekuasaan Majapahit sebagai usaha membentuk kedaulatan dan pertahana di atas wilayah kekuasaan (Paskarina, 2016:2).

Kekuasaan sebagai bagian dari sikap politis yang terbentuk melalui beragam bentuk aktivitas lembaga kekuasaan yang berlaku pada masyarakat di masa lalu. Bentuk dari aktivitas lembaga kekuasaan itu dinyatakan berupa kerajaan. Pembahasan mengenai kerajaan-kerajaan yang pernah berkuasa di Nusantara memberikan sebuah pengetahuan bahwa sebelum terbentuknya Negara Kesatuan Republik Indonesia tahun (NKRI), Indonesia telah melewati masa kekuasaan dengan lembaga yang berdaulat penuh yaitu kerajaan (Mulyana, 2013:81).

Tokoh masyarakat Jawa di masa lalu memainkan peran penting dalam mewujudkan kesadaran nasionalisme karena 
adanya akses-akses pada model kedaulatan. Selain itu, mereka juga tidak sepenuhnya berserah kepada pihak penguasa, melainkan telah terlebih dahulu melakukan penyaringan terhadap pertahanan identitas nasional, sehingga untuk membentuk kedaulatan itu dibutuhkan tindakan-tindakan sebagai langkah untuk menunjukkan persatuan bangsa dan semangat nasionalisme untuk turut serta dalam memperluas daerah kekuasaan kerajaan.

"Armada laut Kerajaan Majapahit akan menjadi armada laut yang kuat jika kesejahteraan prajurit juga diperhatikan dan ditingkatkan. Jadi untuk memperkuat armada laut Kerajaan Majapahit, bukan hanya berarti menambah jumlah kapal Jung. Namun juga meningkatkan kesejahteraan para prajurit pasukan armada laut. Para prajurit akan berjuang sepenuh hati, jika merasa bahwa dengan kuatnya Kerajaan Majapahit, mereka juga akan menikmatinya," tutur Gajah Mada (Soerono, 2014:42).

Kutipan data tersebut memperlihatkan peristiwa ketika Gajah Mada memerintahkan kepada Rakryan Nala, seorang laksamana, untuk membangun armada laut dalam upaya memperkuat pertahanan kerajaan. Realitas yang tergambarkan pada kisah tersebut berbicara tentang pentingnya sebuah kedaulatan laut bagi kerajaan yang berdaulat penuh dengan kekuasaan laut atau maritim, sehingga dengan adanya armada laut yang kuat dapat menjamin stabilitas kelangsungan suatu kerajaan, dan sebagai bentuk perlindungan serangan dari luar kerajaan (Pradhani, 2018:194).

Kekuatan armada Majapahit seperti yang diterangkan dalam Negarakertagama memiliki angkatan laut terbesar di zamannya. Kekuatan angkatan laut ini memiliki tujuan untuk melindungi wilayah-wilayah kekuasaan dari provokasi dan gangguan dari pihak-pihak yang membangkang terutama terhadap pemerintah pusat. Armada Jawa pada saat itu menjadi kekuatan terbesar Majapahit dengan adanya gugusan kapal perang sebagai usaha menjaga pusat pemerintahan. Angkatan laut ini ditempatkan di wilayah pantai utara Jawa yang secara geografis sebagai jalur perdagangan dan pusat induk negara, sedangkan sebagian yang lain disebar untuk mengawasi daerah bawahan yang bertugas menarik upeti. Secara keseluruhan armada ini mampu mengamankan jalannya pemerintahan yang berdaulat (Nugroho, 2011:16).

\subsection{Sumpah dan Perang Sebagai Konsep Maskulinitas dan Nasionalisme Majapahit}

Perkembangan nasionalisme Indonesia sudah ada sejak kerajaan Majapahit berkuasa. Semangat nasionalisme pada saat itu telah digelorakan oleh Maha Patih Gajah mada dengan visi globalisasinya yaitu yang terkenal dengan istilah Sumpah Palapa yang isinya memiliki tujuan untuk menyatukan wilayah Majapahit dengan seluruh wilayah Nusantara (Alfaqi, 2016:211).

Ir. Soekarno menyatakan bahwa sebagian besar wilayah di Indonesia adalah bekas kekuasaan Majapahit. Fakta ini dinyatakan berdasarkan sejarah Majapahit yang telah tertulis, bahwa Majapahit identik dengan penyatuan Nusantara melalui inspirasi Gajah Mada sebagai Mahapatih Amangkubumi berdasarkan sumpah pelantikannya, sumpah palapa (Sutrisno, 2018:9). Oleh sebab itu, pengaruh Majapahit hingga sekarang ini masih membekas bagi masyarakat dan tidak bisa dilupakan dalam perkembangan kekuasaan di Ind onesia.

Turner (2010), memberi gambaran nasionalisme sebuah negara berasaskan keyakinan penuh bahwa orang-orang yang memiliki kesamaan karakteristik seperti bahasa, agama, atau etnis dapat menguasai sebuah komunitas politik yang terpisah dan khas. Paham nasionalisme ini berupaya untuk mengabadikan kekhasan sosialnya sebagai bentuk perlindungan terhadap kepentingan sosial, identitas serta keanggotaan nasional masyarakat di bawah kekuasaan. Sehingga, paham ini cenderung untuk menempatkan legitimasi politik Negara dalam pemerintahan melalui co-nationals (Turner, 2010:366). Nasionalisme telah menjadi 
bahasan dan kajian yang panjang dalam berbagai disiplin, seperti dalam teori politik, sosial, budaya.

Akan Tetapi, identitas dan karakteristik sebagai negeri maritim ini perlahan-lahan mulai memudar karena terbentang oleh rentang waktu yang panjang pada masa awal kemerdekaan hingga sekarang, sehingga nasionalisme yang dibangun sekarang telah membentuk nasionalisme berbasis daratan. Kendatidemikian, Indonesia tetaplah sebagai Negara kepulauan yang membentang dari Sabang hingga Merauke, yang mana dahulunya memiliki sejarah panjang dengan kedaulatan laut sebagai suatu kebangsaan dan merupakan bagian dari warisan budaya .

Pada Kisah pertama dalam Jayaning Majapahit, dibuka dengan kepemimpinan Majapahit III oleh Tribhuwana Tunggadewi. Patih Gajah Mada dikenal dengan sumpah Palapanya Gajah Mada mengucapkan sumpahnya ketika pelantikannya menjadi Mahapatih Amangkabumi di Kerajaan Majapahit (Paramita, 2016). Sumpah ini dikenal sebagai Sumpah Palapa. Isi sumpah menyatakan bahwa Gajah Mada tidak akan memakan buah palapa. Maksud dari palapa adalah, "garam dan rempah-rempah", sehingga Gajah Mada bermaksud untuk mutih, yakni memakan nasi tanpa yang lainnya, walaupun hanya "garam dan rempah". Sumpah ini akan dilakukan Gajah Mada sebagai sampai daerah di seluruh nusantara telah menjadi satu persatuan di bawah panji-panji Majapahit (Sutrisno, 2018:9). Peristiwa sumpah tersebut tergambarkan pada kutipan data berikut.

"Meskipun hakikatnya tidak berbeda, namun apabila Anakmas membungkus sumpah suklabrahmacari itu dengan sumpah tidak akan memakan palapa, aku rasa tidak akan ada yang akan menertawakanmu. Padahal dalam inti sumpah tidak akan memakan palapa itu, juga berarti tidak akan menikmati segala kesenangan dunia, berupa makanan, minuman, kemewahan duniawi dan tentu saja termasuk tidak menyentuh wanita," tutur Dang Acarya (Soerono, 2014:14).
"Sumpah Amukti Palapa memang lebih gagah kedengarannya. Ingsun setuju. Itu yang ingin ingsun cari." Terlihat wajah Gajah Mada menjadi puas. Apa yang dicarinya, ternyata diperolehnya dari Dang Acarya" (Soerono, 2014:16).

Kutipan data berbicara mengenai peristiwa Gajah Mada yang akan melakukan sumpah palapa ketika dilantik menjadi Mahapatih. Kutipan tersebut juga menjelaskan bahwa sumpah yang ingin dilakukan Gajah Mada bukan sekadar sumpah yang diingkari, melainkan sumpah sebagai permintaan yang akan diusahakan. Awalnya, Gajah Mada ingin mengucapkan sumpah suklabrahmacari, sumpah untuk tidak menikah atau menyentuh wanita. Namun, gurunya melarangnya melakukan sumpah suklabrahmacari, melainkan menggantinya dengan sumpah tidak akan memakan palapa. Alasan tersebut disampaikan gurunya karena sumpah sukla brammacari berat untuk dilakukan, bahkan jika bertekad untuk diucapkan bisa menjadi bahan tertawaan orang-orang yang mendengarnya, seolah-olah Gajah Mada bersedia mengorbankan diri untuk mempersatukan Nusantara di bawah bendera kebesaran Kerajaan Majapahit.

Kerangka gender yang dibangun berdasarkan data tersebut adalah masyarakat Majapahit mengenal makna sumpah bukan sekadar kata-kata biasa, namun sebagai suatu kesakralan terutama ketika diucapkan oleh seseorang yang hendak menapaki masa Jabatan yang diterima. Ritual sumpah memiliki makna yang lebih dalam. Secara konsep, sumpah palapa menjadi awal politik Nusantara yang kemudian menjadi awal perkembangan kekuasaan bagi Majapahit.

Kisah Jayaning Majapahit kedua, berbicara tentang perjuangan Raden Wijaya meruntuhkan kerajaan Kadiri dengan bantuan pasukan mongol dari China. Dalam peristiwa ini Raden Wijaya berhasil membunuh Jayakatwang demi membalaskan kematian mertuanya, Kertanegara dari Singasari. 
Kerajaan Majapahit didirikan oleh Raden Wijaya pada tahun 1293 M (Hernawan, 2011:36). Raden Wijaya berhasil mendirikan kerajaan Majapahit setelah memperdayai bala tentara Khubilai Khan dari China yang bermaksud menghukum Raja Jawa yang menghina utusannya, yaitu Meng Chi, yang datang bermaksud menarik upeti kepada Kertanegara namun ditolak. Dalam Jayaning Majapahit diceritakan bahwa Khubilai Khan pertama kali memberi perintah kepada utusannya yang bernama Meng Chi untuk datang ke Singasari dan menuntut Maharaja Kertanegara untuk membayar upeti sebagai tanda takluknya raja Singasari tersebut kepada Khubilai Khan dari kerajaan China. Hal tersebut diinterpretasikan pada kutipan data berikut.

\section{"Mendadak ruang paseban itu dipecahkan oleh jeritan Meng Chi. Ia memegangi kepala bagian kirinya. Darah bercucuran membasahi pakaiannya dan berlumuran di lantai. Di depannya, teronggok sebuah daun telinga. Sri Kertanegara telah memotong telinga Meng Chi. Tetapi Sri Kertanegara belum puas dengan terlepasnya telinga Meng Chi yang teronggok di depan pemiliknya. Dengan sebuah kecepatan kilat kerisnya menyambar wajah Meng Chi yang masih tergolek. Dua buah luka yang saling menyilang, tergores diwajah Meng Chi," (Soerono, 2014:69).}

Kutipan data tersebut menggambarkan bahwa kata "Penaklukan" dianggap sebagai periode kekalahan salah satu pihak ketika perang berakhir. Kekalahan menjadi simbol tunduk bagi suatu kerajaan terhadap kerajaan yang lainnya. Masyarakat bangsawan Jawa pada masa era Majapahit berani mempertaruhkan nyawanya demi mempertahankan harga dirinya, terutama bagi seorang raja yang kekuasaannya sedang terancam, karena bagi Masyarakat bangsawan Jawa kata "ditaklukkan" dapat melecehkan harga diri, terutama jika itu terjadi pada seorang raja yang menjunjung tinggi harga dirinya. Pada peristiwa
Kertanegara yang menggores wajah dan memotong telinga Meng Chi dengan pedangnya, memberikan pemahaman bahwa Kertanegara tidak ingin dicoreng harga dirinya ataupun martabat kerajaan Singasari melalui pembayaran upeti tersebut.

Setelah peristiwa penolakan Kertanegara untuk takluk serta penolakannya membayar upeti, Meng Chi kembali ke China dan melaporkan penganiayaan yang diterimanya kepada Khubilai Khan. Tidak terima atas penghinaan tersebut, Khubilai Khan mengutus Ike Mese menuju Singasari dengan tujuan yang sama yakni memaksa Kertanegara membayar upeti. Namun, ketika pasukan Ike Mese telah sampai di Pulau Jawa, Ia mendapatlan kabar bahwa Kertanegara telah terbunuh oleh Jayakatwang dari Kerajaan Kadiri. Oleh karenanya, Ike Mese meneruskan pembayaran upeti tersebut dengan meminta Raden Wijaya sebagai gantinya. Hal ini dikarenakan, Raden Wijaya merupakan salah satu keturunan sekaligus menantu Kertanegara. Akan tetapi, dengan cerdik Raden Wijaya mengelabui Pasukan Mongol tersebut. Siasat yang dijalankannya adalah ia akan membayar upeti setelah membunuh Jayakatwang sebagai balas dendamnya telah membunuh ayah mertuanya sekaligus menaklukkan Kerajaan Kadiri. Hal tersebut tergambarkan pada kutipan data berikut.

"Karena Jayakatwanglah yang
membunuh ayahdana mertuaku Raja
Kertanegara dari Singhasari. Aku ingin
membalaskan dendam ayahdana
mertuaku. Utang darah dibayar dengan
darah. Utang nyawa dibayar dengan
nyawa," kata Raden Wijaya lagi.
"Selain itu, mana bisa aku membayar
upeti kalau aku diganggu terus menerus
oleh Adipati Jayakatwang?" Alasan
Raden Wijaya itu masuk akal. Memang
tugas seorang anak menantu untuk bela
pati atas kematian orangtuanya.
(Soerono, 2014:82)

Perang bagi orang-orang jawa mempunyai arti yang penting, yakni 
peristiwa untuk menandai suatu proses untuk membawa perubahan. Kendati meletusnya suatu perang memiliki beberapa alasan, di antaranya adanya suatu pemberontakan, tatanan sosial-ekonomi, maupun dari permasalahan keluarga (Carey, 2004:2). Dalam Jayaning Majapahit, meletusnya perang antara Raden Wijaya dan Jayakatwang dilatarbelakangi oleh permasalahan keluarga dan ekonomi. Hal itu tergambarkan dalam kutiapan di atas, yakni kematian Kertanegara dan kedatangan Pasukan mongol yang meminta upeti kepada Raden Wijaya. Perang sebagai tanda akhir sebuah proses, berarti sudah tidak ada jalan keluar untuk menyelesaikan perkara tersebut, sehingga untuk membawa revolusi bagi kerajaan jalan keluar untuk berperang tidak dapat dipatahkan.

Konsep perang yang terjadi dalam Jayaning Majapahit pada dasarnya ialah bagian dari konsepsi maskulinitas dan nasionalisme, yakni sikap Raden Wijaya yang berusaha mengalahkan dan menaklukkan Kadiri melalui perang adalah maskulinitas, sedangkan kemenangan yang diterima oleh Raden Wijaya untuk mengembalikan haknya yang telah dirampas oleh jayakatwang adalah bentuk nasionalisme. Hal ini sesuai dengan teori Nagel (1998), bahwa nasionalisme bersifat politis dan terkait erat dengan suatu Negara, seperti halnya militer. Dengan demikian, pergerakan perang yang didominasi oleh laki-laki dan konsep menasionalkan Negara dengan perang sebagai salah satu strategi politik dalam nasionalisme suatu Bangsa.

Perjuangan nasionalisme melalui jalur perang dilakukan bilamana jalur perdamaian tidak tercapai. Artinya, jalur perang telah menjadi suatu kesepakatan tidak tertulis yang telah dibuat oleh bangsawan Jawa dahulu. Yang dimaksud dengan berjuang ialah melawan pemberontak maupun pengganggu di luar kerajaan yang dapat mengancam sistem tatanan kerajaan, hingga tercapainya kata penaklukan dan kemenangan dalam perjuangan mempertahankan kerajaan tersebut. Untuk melawan pemberontak maupun pengganggu dari luar, bagi bangsaan
Jawa dahulu, pertahanan kerajaan lebih banyak dilakukan dengan perjuangan bersenjata lebih tepatnya dengan peperangan.

\subsection{Sistem Politik Sebagi Bentuk Nasionalisme Majapahit}

Sejak abad ke-5 masyarakat Jawa kuna sudah mengenal yang namanya sistem pemerintahan. Pemerintahan tersebut berupa sistem kerajaan. Tercatat ada beberapa kerajaan yang pernah menjadi penguasa di tanah Jawa, beberapa di antaranya adalah Singasari, Kadiri, dan Majapahit (Skripsi: Sofyan, 2010).

Kerajaan Majapahit merupakan kerajaan Hindu-Buddha terbesar di Nusantara. Kepemimpinan pada masa tersebut masih dipengaruhi oleh pandangan dan konsep ajaran agama yang dianut. Pada dasarnya, ajaran-ajaran tentang kehidupan dan moral Hindu dan Buddha terdapat dalam karyakarya sastra dari India yang kemudian digubah oleh para pujangga Jawa, sesuai dengan kearifan lokal sehingga kebudayaan Jawa tidak tercabut dari akarnya (Zoetmulder, 1985:10).

Majapahit sebagai kerajaan yang telah memperlihatkan kehidupan kompleks tentunya telah merencanakan sistem birokrasi yang rapi dalam mengurusi banyak bidang, berjenjang maupun politis. Sistem yang berlaku pada saat kekuasaan majapahit berjaya, tentunya sudah ada dari masa-masa sebelumnya yang kemudian berkembang seiring berjalannya tuntutan zaman dan sebagian yang lain mulai diadopsi bagi masa sesudahnya (Wahyudi, 2013:90). Bahkan, permainan ekonomi pada tingkat regional nusantara, Majapahit terlihat cukup dominan, bahkan dalam bidang politik serta ekonomi. Hal ini didasarkan pada kecanggihan maritim Majapahit yang diakui sebagai salah satu yang termaju pada zamannya, terutama memiliki banyak sekali kapal-kapal besar peninggalan dari pasukan mongol yang telah dalam kisahnya berhasil dikalahkan oleh Raden Wijaya.

Rickleft memberikan beberapa tandatanda secara umum bagaimana kondisi negara Indonesia ketika masih berupa sistem 
kerajaan. Tanda-tanda tersebut terangkum dalam kurun waktu beberapa abad ke depan tidak mengalami perubahan signifikan. Hal ini karena dipengaruhi oleh kondisi tanah dan iklim yang ada di daerah-daerah tersebut, terutama dalam sektor perdagangan, pertanian, serta terhadap formasi negara. Selain itu, letak geografis kerajaan yang strategis, diapit oleh kepulauan dan luas daratan yang daratan, sehingga masyarakat memiliki beberapa mata pencaharian, yakni sebagai nelayan bagi yang tinggal di dekat dermaga maupun bercocok tanam bagi yang tinggal di pedalaman. Dengan demikian, kerajaan semakin makmur karena kecenderungan untuk melakukan perdagangan akibat letak strategis yang memiliki pelabuhan-pelabuhan dan kapalkapal besar untuk mengarungi lautan serta menjalin kerja sama menguntungkan dengan kerajaan lain di luar kerajaan.

Untuk kepemimpinan, kerajaan dipimpin oleh Raja atau Ratu. Raja atau Ratu adalah orang yang memiliki kekuasaan tertinggi. Seorang pemimpin oleh masyarakat Jawa dahulu yang masih menganut kepercayaan Hindu-Budha, diibaratkan sebagai penjelmaan dewa di dunia yang memegang otoritas politik dan menduduki hierarki tertinggi di kerajaan. Artinya kontrol nasionalise dalam kerajaan dipegang oleh seseorang yang memegang kekuasaan, seperti halnya Raja atau Ratu.

"Sri Ratu tidak ingin terjadi hal seperti itu dalam masa pemerintahannya. Betapa pun upaya Gajah Mada untuk dapat mewujudkan Sumpah Amukti Palapa, namun apabila para perwira tinggi Kerajaan Majapahit bergolak sendiri, berbenturan sendiri di antara mereka, maka semuanya akan sia-sia belaka. Karena itu, Sri Ratu menaruh perhatian yang lebih besar ketika ada seseorang yang akan dipromosikan atau menjabat pangkat setingkat lebih tinggi (Soerono, 2019:39).

Kutipan data di atas menunjukkan bahwa tugas utama raja dalam bidang politik adalah menjaga sistem pemerintahan agar stabil dan terhindar dari provokasi dari luar dalam masa pemerintahannya maupun pemerintahan raja selanjutnya. Apabila tidak dapat dihindari terjadi suatu provokasi, maka raja bertugas untuk segera memulihkan dan memberantas semua gangguan yang akan, sedang dan telah terjadi. Seorang raja atau ratu yang memimpin suatu wilayah memiliki peran khusus dalam kehidupannya dan keharusannya untuk menjaganya keseimbangan kerajaan. Peran yang dimiliki oleh setiap raja-raja di Jawa ini mempunyai tujuan agar legitimasinya sebagai penguasa tidak hilang (Nurhayati, 2006:68-69). Untuk mencapai titik tersebut, seorang pemimpin harus mampu mengasosiasikan dengan baik relasi antara hal yang mikrokosmos dan hal yang makrokosmos (Nurhayati, 2006:64). Dengan demikian, hubungan antara kerajaan dan masyarakat yang dipimpinnya akan lahir keharmonisan, apabila kerajaan dapat dikelola melalui sistem politik yang benar.

Dalam karya sastra Hindu-Budha dari india disebutkan bahwa raja harus memiliki sifat-sifat yang kekal anugerah dari dewa. Beberapa di antara sifat tersebut diinterpretasikan sebagai berikut. Pertama, Dewa Bayu (Dewa Angin) yang diartikan memiliki falsafah yang teliti dan nalar yang dalam sehingga raja harus selalu mengetahui keadaan lapisan masyarakatnya berserta gejolak yang sedang terjadi di bawah kepemimpinannya. Kedua, Dewa Yama (Dewa Maut) yang diartikan memiliki kemampuan untuk menekan semua kejahatan, sehingga raja harus menegakkan hukum dan keadilan tanpa pandang bulu; dan Dewa Agni (Dewa Api) yang memiliki membinasakan musuh-musuhnya dengan cepat, sehingga raja harus segera melenyapkan musuh-musuh atau mendepak orang-orang yang dapat mengganggu jalannya pemerintahan (Darini, 2019:103104).

\section{Kesimpulan}

Uraian tentang maskulinitas dan nasionalisme dalam masyarakat jawa yang diperoleh dalam Novel Jayaning Majapahit 
memiliki kecenderungan maskulin dengan ditandai ad anya interpretasi peran perempuan yang sedikit, sedangkan peran yang bersentuhan dengan dunia laki-laki, yakni nasionalisme dan peperangan tampak mendominasi. Paradigma maskulinitas masyarakat Jawa terhadap laki-laki digambarkan melalui peristiwa peperangan sebagai konstruksi maskulin dalam budaya, sedangkan perannya dalam membela negara adalah bentuk nasionalisme.

Wacana kedudukan tokoh laki-laki dalam Novel Jayaning Majapahit lebih mendominasi dalam urusan kedaulatan kerajaan Majapahit, baik dalam urusan mengatur strategi politik dalam pemerintahan maupun mengatur strategi perang. Melalui dua bentuk dominasi maskulinitas tersebut, masyarakat Majapahit secara spesifik menempatkan posisi laki-laki berada di level tertinggi dalam situasi posisi terkait menjaga dan mempertahankan keutuhan negara.

Kedaulatan yang bekerja di lingkungan Majapahit menjadi dasar nasionalisme dalam memperkuat daerah kekuasaan. Hal ini terinterpretasikan melalui Gajah Mada yang memberikan perintah kepada Rakryan Nala untuk membangun Armada laut sebagai upaya mempertahakan kekuasaan Majapahit. Dengan demikian, dinamika maskulinitas dan nasionalisme masyarakat Jawa yang dapat diambil pandangannya ialah upaya meletakkan urusan negara yang bersifat militer atau peperangan kepada laki-laki karena telah adanya suatu sudut pandang bahwa laki-laki dalam urusan posisi hierarki memiliki peran khusus yang mampu mendominasi.

\section{Daftar Pustaka}

Alfaqi, M. Z. (2016) "Melihat Sejarah Nasionalisme Indonesia Untuk Memupuk Sikap Kebangsaan Generasi Muda," Jurnal Pendidikan Pancasila dan Kewarganegaraan, 13(2), hal. 111116. doi: http://journal.um.ac.id/index.php/jppk/a rticle/view/5451.

Budiman, H. G., dan Sofianto, K. (2018)
"Representasi Sipil-Militer dan Konstruksi Maskulinitas Pada Film Jenderal Soedirman (2015) ," Paradigma: Jurnal Kajian Budaya, 8(2), hal. $155 . \quad$ doi: 10.17510/paradigma.v8i2.220.

Budiman, H. G., Priyatna, A., dan Mulyadi, R. M. (2019) "Maskulinitas Tentara Dalam Sinema Pasca Orde Baru; Analisis Naratif Doea Tdana Cinta (2015) Dan I Leave My Heart in Lebanon (2016)," Patanjal: Jurnal Penelitian Sejarah dan Budaya, 11(1), hal. $131 . \quad$ doi: 10.30959/patanjala.v11i1.483.

Carey, B. R. (2004). Asal-Usul Perang Jawa, Pemberontakan Sepoy \& Lukisan Raden Saleh. LKiS: Yogyakarta.

Darini, R. (2019) "Kiprah Perempuan Majapahit di Ruang Politik," Patrawidya, 20(1), hal. 101-113. doi: http://download.garuda.ristekdikti.go.id/ article.php?article $=1094530 \& v a l=1468$ 2\&title=KIPRAH\%20PEREMPUAN\% 20MAJAPAHIT\%20DI\%20RUANG\% 20POLITIK.

Demartoto, A. (2010) “Konsep Maskulinitas Dari Zaman Ke Zaman dan Citranya Dalam Media”. doi: https://argyo.staff.uns.ac.id/2010/08/10/ konsep-maskulinitas-dari-zaman-kezaman-dan-citranya-dalam-media.

Endraswara, S. 2011. Metodologi Penelitian Sastra. Cetakan Ke-1. Jakarta: Caps.

Hernawan, W. (2011) "Perang Bubat dalam Literature Majapahit," Jurnal Ilmiah Agama dan Sosial Budaya, 34 (1), hal. 35-43. doi: http://digilib.uinsgd.ac.id/3718.

Huda, M. (2017) "Legenda Candi Prambanan dan Gunung Kunci: Kajian Sastra Maskulin," Urecol Proceeding: UAD Yogyakarta, hal. 1080-1085.

Jatnika, A. W., dan Hermawan, F. F. (2018) 
"Menjadi Lelaki Sejati: Maskulinitas Dalam Komik Daring Webtoon Indonesia," Mudra: Jurnal Seni Budaya, 33(1), hal. $60 . \quad$ doi: 10.31091/mudra.v33i1.158.

Mulyana, A. (2013) "Nasionalisme dan Militerisme: Ideologisasi Historiografi Buku Teks Pelajaran Sejarah Sma," Paramita: Historical Studies Journal, 23(1), hal. 78-87. doi: 10.15294/paramita.v23i1.2498.

Nagel, J. (1998) Masculinity and nationalism: gender and sexuality in the making of nations, Ethnic and Racial Studies, 21:2, 242-

269, DOI: $\underline{10.1080 / 014198798330007}$

Nugroho, I. D. 2011. Majapahit Peradaban Maritim Ketika Nusantara Menjadi Pengendali Pelabuhan Dunia. Jakarta: Yayasan Suluh Nuswantara Bakti.

Nurhayati, E. 2006. Filsafat dan Ajaran Hidup: Dalam Khasanah Budaya Keraton Yogyakarta. Yogyakarta: YKIIUIN Sunan Kalijaga.

Paramita, D. W. (2016) "Pendidikan Karakter dalam Lambang Surya Majapahit," Skripsi, Universitas Negeri Yogyakarta. doi: Http://Eprints.Uny.Ac.Id/33324/1/TAS \%20WIDYANTARI\%20DYAH\%20PA RAMITA.PDF.

Paskarina, C. (2016) "Wacana Negara Maritim Dan Reimajinasi Nasionalisme Indonesia," Jurnal Wacana Politik, 1(1), hal 1-8. doi: 10.24198/jwhal.v1i1.10542.

Pradhani, S. I. (2018) "Sejarah Hukum Maritim Kerajaan Sriwijaya dan Majapahit dalam Hukum Indonesia Kini," Lembaran Sejarah, 13(2), hal. 186. doi: 10.22146/lembaransejarah.33542.
Rickleft, M. C. 2005. Sejarah Indonesia Modern 1200-2004. Jakarta:Serambi Ilmu Semesta.

Soerono, A. S. 2014. Jayaning Majapahit: Kisah Para Kesatria Penjaga Samudra. Jakarta: Gramedia Pustaka Utama.

Sofyan, Y. M. (2010) "Kekuasaan Jawa: Studi Komparatif Sistem Kekuasaan Kerajaan Majapahit dan Demak," Skripsi Universitas Islam Negeri Syarif Hidayatullah, hal. 1-105. doi:http://repository.uinjkt.ac.id/dspace/ hdanle/123456789/2212.

Sutrisno, I. H. 2018 "Makna Sumpah Palapa Bagi Nusantara (Kajian Ekspedisi Pamalayu Dalam Konsep Nasionalisme Majapahit)," Seuneubok Lada: Jurnal Ilmu-ilmu Sejarah, Sosial, Budaya dan Kependidikan, 5(1), hal. 7-15. doi: https://doi.org/ 10.1017/s0022463401000157.

Syaifullah, J. (2016) “Analisis Semiotik Tentang Kekuasaan dan Maskulinitas Pada Tampilan Website Gudang Garam Pria Punya Selera," Jurnal Informa Politeknik Indonusa Surakarta, 1(3), hal. 23-36. doi: https://informa.poltekindonusa.ac.id/ index.php/informa/article/view/121.

Turner, G. (1999). Film as Social Practice. New York: Routledge.

Wahyudi, D. Y. (2013) "Kerajaan Majapahit: Dinamika Dalam Sejarah Nusantara1," Sejarah Dan Budaya, 7(1) hal. 88-95. doi: http://training.um.ac.id/ojs/index.php/se jarah-danbudaya/article/view/4739/2270.

Widiana, A. (2017) "Konstruksi Gender Tokoh Sabari dalam Novel Ayah Karya Danrea Hirata; Analisis Wacana Teun A. Van Dijk" Skripsi: Institut Agama Islam Negeri Surakarta. doi: http://eprints.iain-surakarta.ac.id/2280. 
Wiyatmi. (2013). "Konstruksi Nasionalisme dalam Novel-Novel Indonesia Prakemerdekaan (Student Hijo Dan Salah Asuhan )," Kawistara, 3(2), hal. 117-226. doi: https://jurnal.ugm.ac.id/kawistara/article /view/3980.

Zoetmulder, J. 1985. Kalangwan: Sastra Jawa Kuna Selayang Pdanang. Jakarta: Djambatan. 